\title{
Yield, Tryptophan and Lysine Content of Two Quality Protein Maize Varieties in Two Luvisols with Bio Fertilization in Yucatan, Mexico
}

\section{Jorge H. Ramírez-Silva1 ${ }^{*}$, Yolanda Moguel-Ordóñez ${ }^{2}$, Mónica Guadalupe Lozano-Contreras², Genovevo Ramírez-Jaramillo ${ }^{1}$}

${ }^{1}$ Centro de Investigación Regional Sureste del Instituto Nacional de Investigaciones Forestales, Agrícolas y Pecuarias (INIFAP), Mérida, Yucatán, México

${ }^{2}$ Campo Experimental Mocochá del Instituto Nacional de Investigaciones Forestales, Agrícolas y Pecuarias (INIFAP), Mocochá, Yucatán, México

Email: *ramirez.jorge@inifap.gob.mx

How to cite this paper: Ramírez-Silva, J.H., Moguel-Ordóñez, Y., Lozano-Contreras, M.G. and Ramírez-Jaramillo, G. (2020) Yield, Tryptophan and Lysine Content of Two Quality Protein Maize Varieties in Two Luvisols with Bio Fertilization in Yucatan, Mexico. Open Access Library Journal, 7: e6572.

https://doi.org/10.4236/oalib.1106572

Received: July 3, 2020

Accepted: July 25, 2020

Published: July 28, 2020

Copyright $\odot 2020$ by author(s) and Open Access Library Inc.

This work is licensed under the Creative Commons Attribution International License (CC BY 4.0).

http://creativecommons.org/licenses/by/4.0/

(c) (i) Open Access

\begin{abstract}
This work was carried out in Yucatan Mexico aiming to evaluate the yield performance, Tryptophan (Trp) and Lysine (Lys) contents of two quality protein maize varieties (Sac Beh and Chichen Itza) growing in two Luvisols with low (Lot 1) and high (Lot 2) intensive agricultural use. Six treatments resulted from combining the two varieties with chemical fertilizers (60-80-00): $\left(\mathrm{N}-\mathrm{P}_{2} 0_{5}-\mathrm{K}_{2} \mathrm{O}\right)$ alone or supplemented with biofertilizers (60-80-00 + Mycorrhizae + Azospirillum) and the control (00-00-00). The variables were: yield $\left(\mathrm{t} \cdot \mathrm{ha}^{-1}\right)$, Trp, Lys ( $\mathrm{g}$ of amino acid/100 $\mathrm{g}$ of protein), Ashes (\%) and Crude Protein (\%). A Randomized block design was used with three replications for yield, ashes and crude protein and two replications for Trp and Lys. Statistical differences were found only in ashes. Regardless of the intensive soil use both varieties showed good yields, ranging from 5.0 to 6.5 tha ${ }^{-1}$. Higher yields were documented in the low intensive use Luvisol (Lot 1). The higher yields, in Lot 1, were obtained with (T Chem-Bio) whilst in Lot 2 was with (T Chem). Yields increased with the application of chemical fertilizers alone or in combination with biofertilizers but the amount of Trp and Lys decreased. Sac Beh showed to have better protein quality than Chichen Itza but none of them reached the optimal ranges reported in the literature, so more evidence is required to start with a plan to rescue and maintain the protein quality of both varieties.
\end{abstract}

\section{Subject Areas}

Agricultural Science, Soil Science 


\section{Keywords}

Soil Fertility, Nutrition, Fertilization, Protein

\section{Introduction}

The soils of Yucatan Peninsula in Mexico are completely heterogeneous [1]. The soil fertility and crop productivity can be easily lost due to intensive cultivation when high amount of fertilizers is being used. In this region, as in the Mexican Republic, corn is a staple food and more than an average of 390 thousand hectares are being planted. The problem, being faced, is the use of native corn varieties with low yield potential and poor protein quality such as the Lysine (Lys) and Tryptophan (Trp) amino acids.

Normal corn is deficient in the presence of the essential amino acids Lys and Trp. Consequently, when people's diets are primarily based on corn, consumers are at risk of malnutrition, especially those who require high levels of protein such as young children and pregnant or lactating women. Conventionally improved Quality Protein Maize (QPM) grain has been shown to improve nutritional status.

Corn protein is of low nutritional value as the result of an amino acid imbalance and low protein content [2] and it is deficient in Lys and Trp [3]. The current agronomic and nutritional characteristics of maize with high protein quality (Quality Protein Maize, QPM) are largely due to the work done by Surinder K. Vasal, geneticist at the International Maize and Wheat Improvement Center (CIMMYT) and Evangelina Villegas, biochemist and former researcher at CIMMYT [4].

Keeping in mind the CIMMYT's improvement maize program, the National Institute for Forestry, Agriculture and Livestock Research of Mexico (INIFAP) focused its attention on improving the protein quality of native Mayan corn. In 2010, INIFAP launched, to the market, two new QPM maize varieties named: Chichen Itza and Sac Beh adapted to the stony areas containing over 50\% Lys and $\operatorname{Trp}$ as compared to other no improved native maize and exceeding $2.5 \mathrm{t} \cdot \mathrm{ha}^{-1}$ [5].

Although some research has been carried out to evaluate the variations of protein quality in different corn materials, when submitted to different environments [6] [7], none has been done in the specific case of Chichen Itza and Sac Beh. The object of this work was: 1) to evaluate the yield performance, and Lys and Trp content in Chichen Itza and Sac Beh in two different intensive use arable Luvisols, and 2) to assess the effect of applying chemical fertilizers, alone or combined with biofertilizers, on yield and protein quality.

\section{Materials and Methods}

The work was carried out in the south part of the state of Yucatan, Mexico under 
good rainfed conditions, during spring-summer 2017, at the INIFAP-UXMAL Experimental Station $\left(20^{\circ} 29^{\prime} 08.1^{\prime \prime}\right.$ north latitude and $89^{\circ} 24^{\prime} 39^{\prime \prime}$ west longitude), at an altitude of 50 masl. The precipitation and annual average temperature are $900 \mathrm{~mm}$ and $25^{\circ} \mathrm{C}$ respectively. Sac Beh and Chichen Itza were planted in two Luvisols with low (Lot 1) and high (Lot 2) intensive agriculture use. Lot 1 with frequent fallow period whilst Lot 2 with more than 20 consecutive years of agricultural use.

Chichen Itza and Sac Beh are free-pollinated varieties with a biological cycle ranging from 130 to 140 days and with a potential yield of five tons per hectare in the shifting (Milpa Maya) cultivation areas of Yucatan, Mexico as compared to the 0.8 tons per hectare of the native varieties.

\subsection{Soil Nutrient Content in the Study Area}

Depending on the intensive use of the soil, two experimental lots with soils classified as Luvisols were selected. The first one (Lot 1) was an area of low agricultural intensive use since corn has been planted sporadically every 4 to 5 years with longer fallow periods. On the other hand, the second area (lot 2) refers to a Luvisol where corn has been grown every year, with fertilizers and irrigation, for more than 20 years without any fallow period. These differences drove to the contrasting nutritional contents of both soils, specifically changes in salinity and phosphorus content.

The pH's of both soils are neutral, but they differ because Lot 1 has a lower Electrical Conductivity $(\mathrm{EC}=0.66 \mathrm{mS} / \mathrm{cm})$ than Lot $2(1.53 \mathrm{mS} / \mathrm{cm})$, classified as low and medium $\mathrm{CE}$ respectively. Sodium $(\mathrm{Na})$ is considerably higher in Lot 2 (330 vs. $165 \mathrm{ppm}$ ). Even though, Organic Matter (OM) is satisfactory in both lots, the content is higher in Lot $1(2.78 \%$ vs. $2.11 \%)$. Phosphorus (P) in Lot 1 is in the optimal range (17 ppm) but in Lot 2 , with more intensive use, $\mathrm{P}$ is in excess with $80 \mathrm{ppm}$ due to frequent fertilizer applications. Potassium (K), Calcium (Ca) and Magnesium ( $\mathrm{Mg}$ ) contents are excessive in both Lots but they face Iron (Fe) deficiencies.

\subsection{Treatments, Variables and Statistical Analysis}

Six treatments were studied in experimental plots of $5 \mathrm{~m} \times 4 \mathrm{~m}\left(20 \mathrm{~m}^{2}\right)$ with four rows $1 \mathrm{~m}$ wide and $5 \mathrm{~m}$ long getting a population density of 50,000 plants ha ${ }^{-1}$. The treatments: T1 00-00-00-Chichen Itza (Cnt-Chi), T2 00-00-00-Sac Beh (Cnt-Sac), T3 60-80-00-Chichen Itza (Chem-Chi), T4 60-80-00-Sac Beh (Chem-Sac), T5 60-80-00 + Mycorrhizae + Azospirillum-Chichen Itza (Chem-Bio-Chi), T6 60-80-00 + Mycorrhizae + Azospirillum-Sac Beh (Chem-Bio-Sac) were the result of applying, to both varieties Chichen Itza (Chi) and Sac Beh (Sac), a basic dose of a chemical fertilization (N-P $\left.\mathrm{P}_{2}-\mathrm{K}_{2} \mathrm{O}\right)$ : (60-80-00) alone (T Chem) or supplemented (T Chem-Bio) with biofertilizers (60-80-00 + Mycorrhizae + Azospirillum) and a non-treated ( $\mathrm{T}$ Cnt) control (00-00-00), arranged in a randomized complete block design. The variables measured were: Yield of grain $\left(t \cdot h a^{-1}\right)$, Lys and Trp content both ex- 
pressed as grams of amino acid in $100 \mathrm{~g}$ of protein, Protein (\%) and Ashes (\%). Three replications were for yield, protein and ashes, and two for the amino acids.

Analysis of Variance (ANOVA) was calculated, to all variables, in order to see statistical differences among the six treatments. When statistical differences were found, as in the specific case of ashes, a Tukey test at $p=95 \%$, was run off to select the best treatment. The confidence of the information was obtained by calculating the Coefficient of Variation $(\mathrm{CV})$ to all variables as related to the six treatments.

\subsection{Biofertilizers Inoculation}

The seeds were inoculated with a mixture (1:1 ratio) of both: 1$)$ INIFAP ${ }^{\mathrm{MR}}$ brand biofertilizer with Rhizophagus intraradices, as active ingredient, in a concentration of $\geq 60$ spores and 2) Azospirillum brasilense in a concentration of $1 \times 10^{-6}$ colony forming units (CFU) $\mathrm{mL}^{-1}$. Once the seeds were inoculated, they were dried at room temperature for 8 hours. After drying, seeds were sown in definite experimental plots.

\subsection{Lysine and Tryptophan Determination}

The amino acid profile (Lys and Trp) was determined by using a high performance liquid chromatography (HPLC) according to Alaíz et al., (1992) [8] and Yust et al., (2004) [9]. Amino acids were quantified using calibration curves at concentrations of 50, 250, 500, 1000, 2000, $4000 \mathrm{pmol} / 20 \mu \mathrm{L}$ for each amino acid; starting from a stock solution of the L-amino acids at $5 \mu \mathrm{mol} / \mathrm{mL}$ elaborated with commercial standards.

\subsection{Crude Protein and Ashes Determination}

Grain samples were ground using a Willey knife mill with a screen size of $1 \mathrm{~mm}$. Crude protein was determined using Kjeldhal according to the AOAC Method 954.01 [10]. A factor of 6.25 was used as a nitrogen to protein conversion factor. The ashes were determined using the AOAC Method 923.03 [11]. Inorganic residues were the remains resulted after incineration of organic matter at $550^{\circ} \mathrm{C}$ for $4 \mathrm{~h}$.

\section{Results and Discussion}

\subsection{Statistical Analysis}

With the exception of ashes, no significant differences were found among the six treatments when information of each variable was submitted to the ANOVA analysis (Table 1 and Table 2).

For all cases the Degree of Freedom (Df) was $t-1=5$ according to statistical procedures when the number of treatments are six. The Comparison of Means using the Tukey test at $\mathrm{p}=95 \%$ was performed only for the ash content variable since the other ones did not show significant differences among treatments according to ANOVA. As shown in Table 2, the content of Tryptophan and Ly- 
sines in all six treatments and both lots did not show statistic differences so Comparison of Means was not determined.

Uribe-Valle and Petit-Aldana in 2007 [12], found no statistical differences among yields of maize Variety 539, when comparing treatments of Mycorrhizae + Azospirillum inoculations versus a chemical treatment (40-100-00) and the control (00-00-00) in a Luvisol of Yucatán. The CV (\%) ranged, in Lot 1, from 6.02 to 26.03 for crude protein and Tryptophan respectively; the same trend happened to Lot 2, ranging from 8.35 for crude protein and the highest value of 56.31 for Tryptophan. Pimentel, (1985) [13] indicates that the CV's can be different according to the type of the experiments. Other authors [14] [15] [16] indicate that CV's above $30 \%$ are of low precision.

\subsection{Yield (t"ha-1) for Chichen Itza and Sac Beh in Lots 1 and 2}

\section{Grain Yield Chichen Itza Lot 1 and Lot 2}

Chichen Itza showed (Table 3) the highest yield $\left(6.80 \mathrm{t} \cdot \mathrm{ha}^{-1}\right)$ when applying the combined treatment (T Chem-Bio-Chi), followed by the control (T Cnt-Chi) with $6.55 \mathrm{t}^{-h^{-1}}$ and the chemical treatment (T Chem-Chi) with $6.34 \mathrm{t} \cdot \mathrm{ta}^{-1}$ without showing significant differences. The narrowed yield gap between the ( $\mathrm{T}$ Cnt-Chi) and the other treatments suggests a low response of Chichen Itza to chemical fertilizers when growing under low intensive use land as the Lot 1 . This suggests that the low intensive use Lot 1 could supply good enough nutrients to the crop. There was a slight response to biofertilizers.

Table 1. Mean squares and statistical significance of the traits evaluated for yield $\left(\mathrm{t} \cdot \mathrm{ha}^{-1}\right.$, Crude Protein (\%) and Ashes (\%).

\begin{tabular}{cccccccc}
\hline $\begin{array}{c}\text { Source of } \\
\text { Variation }\end{array}$ & Df & $\begin{array}{c}\text { Yield } \\
\text { Lot 1 }\end{array}$ & $\begin{array}{c}\text { Yield } \\
\text { Lot 2 }\end{array}$ & $\begin{array}{c}\text { Protein } \\
\text { Lot 1 }\end{array}$ & $\begin{array}{c}\text { Protein } \\
\text { Lot 2 }\end{array}$ & $\begin{array}{c}\text { Ashes } \\
\text { Lot 1 }\end{array}$ & $\begin{array}{c}\text { Ashes } \\
\text { Lot 2 }\end{array}$ \\
\hline Treatments & 5 & $1.946 \mathrm{~ns}$ & $4.199 \mathrm{~ns}$ & $0.639 \mathrm{~ns}$ & $0.642 \mathrm{Ns}$ & $3.856^{*}$ & $7.910^{*}$ \\
Repetitions & 2 & $0.067 \mathrm{~ns}$ & $2.918 \mathrm{~ns}$ & $0.368 \mathrm{~ns}$ & $1.407 \mathrm{Ns}$ & $0.056 \mathrm{~ns}$ & $0.310 \mathrm{Ns}$ \\
Error & 10 & 10.883 & 3.441 & 4.364 & 6.923 & 0.726 & 0.724 \\
CV (\%) & & 16.07 & 10.88 & 6.02 & 8.35 & 18.00 & 19.85 \\
\hline
\end{tabular}

${ }^{*}$ significant at $\mathrm{p}<0.01$ and $\mathrm{p}<0.05$, respectively; $\mathrm{ns}=$ not significant; $\mathrm{EE}=$ Experimental Error, $\mathrm{CV}=\mathrm{Varia}-$ tion coefficient.

Table 2. Mean Squares and statistical significance of the traits evaluated for Tryptophan and Lysine Content ( $\mathrm{g}$ of aminoacid/100 $\mathrm{g}$ of protein) in grains of Chichen Itza and Sac Beh varieties in two Luvisols.

\begin{tabular}{cccccc}
$\begin{array}{c}\text { Source of } \\
\text { Variation }\end{array}$ & Df & $\begin{array}{c}\text { Tryptophan } \\
\text { (Lot 1) }\end{array}$ & $\begin{array}{c}\text { Tryptophan } \\
\text { (Lot 2) }\end{array}$ & $\begin{array}{c}\text { Lysine } \\
\text { (Lot 1) }\end{array}$ & $\begin{array}{c}\text { Lysine } \\
\text { (Lot 2) }\end{array}$ \\
\hline Treatments & 5 & $0.145 \mathrm{~ns}$ & $0.145 \mathrm{~ns}$ & $1.114 \mathrm{~ns}$ & $1.271 \mathrm{~ns}$ \\
Repetitions & 1 & $0.001 \mathrm{~ns}$ & $0.064 \mathrm{~ns}$ & $0.004 \mathrm{~ns}$ & $0.891 \mathrm{~ns}$ \\
Error & 5 & 0.036 & 0.204 & $0.956^{*}$ & 1.893 \\
CV (\%) & & 26.63 & 56.31 & 20.46 & 25.05 \\
\hline
\end{tabular}

${ }^{*}$ significant at $\mathrm{p}<0.01$ and $\mathrm{p}<0.05$, respectively; $\mathrm{ns}=$ not significant; $\mathrm{EE}=$ Experimental Error, $\mathrm{CV}=\mathrm{Varia}-$ tion coefficient. 
Table 3. Yield Performance $\left(\mathrm{t} \cdot \mathrm{ha}^{-1}\right)$ of Chichen Itza and Sac Beh under different treatments in low (Lot 1) and highly intensive (Lot 2) Luvisols.

\begin{tabular}{cccccc}
\hline $\begin{array}{c}\text { Fertilization } \\
\text { Treatments }\end{array}$ & $\begin{array}{c}\text { Chichen Itza } \\
\text { (LOT 1) }\end{array}$ & $\begin{array}{c}\text { Chichen Itza } \\
\text { (LOT 2) }\end{array}$ & $\begin{array}{c}\text { Sac Beh } \\
\text { (LOT 1) }\end{array}$ & $\begin{array}{c}\text { Sac Beh } \\
\text { (LOT 2) }\end{array}$ & Average \\
\hline (T Cnt) & 6.55 & 5.29 & 5.84 & 4.77 & 5.61 \\
(T Chem) & 6.34 & 6.09 & 6.68 & 5.71 & 6.20 \\
(T Chem-Bio) & 6.80 & 5.68 & 6.74 & 4.82 & 6.01 \\
Average & 6.56 & 5.68 & 6.42 & 5.10 & 5.94 \\
\hline
\end{tabular}

T Control (00-00-00), the applied chemical fertilizer dose was ( $60 \mathrm{~kg} \mathrm{~N} / \mathrm{ha}, 80 \mathrm{~kg}_{2} \mathrm{O}_{5} / \mathrm{ha}$ and $0 \mathrm{~kg} \mathrm{~K} / \mathrm{O} / \mathrm{ha}$ ); T Chemical-Biofertilizers (60-80-00 + Mycorrhizae + Azospirillum).

On the other hand, Chichen Itza in Lot 2, showed the highest yield (6.09) when applying ( $\mathrm{T}$ Chem-Chi) followed by the combined one (T Chem-Bio-Chi) with 5.68 and the lowest yield (5.29) was found in the (T Cnt-Chi). It seems that Lot 2 with highly intensive use could not provide sufficient nutrients to the crop, so a complement with chemical fertilization (T Chem-Chi) alone or combined (T Chem-Bio-Chi) was needed to get better yields.

\section{Grain Yield Sac Beh Lot 1 and Lot 2}

As in the case of Chichen Itza in Lot 1, Sac Beh achieved the highest yield

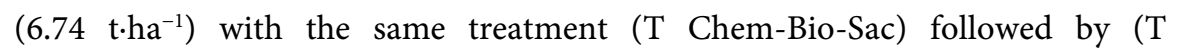
Chem-Sac) with $6.68 \mathrm{t} \cdot \mathrm{ha}^{-1}$ and the lowest one with the control (T Cnt-Sac) with $5.84 \mathrm{t} \cdot \mathrm{ha}^{-1}$ respectively (Table 4 ).

Similarly, to Lot 1 , in lot 2 the control (T Cnt-Sac) obtained the lowest yield $\left(4.77 \mathrm{t} \cdot \mathrm{ha}^{-1}\right)$ whilst the highest one was for (T Chem-Sac) with $5.71 \mathrm{t} \cdot \mathrm{ha}^{-1}$. The ( $\mathrm{T}$ Chem-Bio-Sac) had a very similar yield (4.82 $\left.\mathrm{t} \cdot \mathrm{ha}^{-1}\right)$ as that one found in the (T Cnt-Sac).

\section{Lot 1 vs Lot 2}

Chichen Itza and Sac Beh showed an important yield reduction in Luvisol of Lot 2 with the highly intensive use. This can be related to the double content of $\mathrm{Ec}$ and $\mathrm{Na}$ as compared to Lot 1 as mentioned before. The degree of yield reduction between the two varieties suggests that Chichen Itza may be better adapted than Sac Beh to soils that have had greater intensive agricultural use. This can be observed when comparing the overall average yields (Table 3 ) of both varieties obtained in the highly intensive use Luvisol (Lot 2) where Chichen Itza had a higher yield than Sac Beh (5.68 vs $5.10 \mathrm{t} \cdot \mathrm{ha}^{-1}$ ). By the way, corn has been classified as a very sensitive crop to salt stress [17]. Rengasamy et al., (2010) [18] indicate that excessive salt accumulation is possible due to irrigation and agricultural activity.

In Yucatan Mexico soils can face important salinization problems due to both irrigation waters and intensive agricultural use. The origin of salinization is well described by Bautista et al., in 2005b [19]. Despite adverse conditions of salinity and sodicity; the yields of both QPM varieties (Table 4) were superior than the $2.5 \mathrm{t} \cdot \mathrm{ha}^{-1}$ suggested for stony soils and it could be proved that yield can be even higher than $5.0 \mathrm{t}^{\mathrm{h}} \mathrm{h}^{-1}$, as proposed by Aguilar-Castillo. et al., in 2010 [5], when they are grown in arable Luvisols of Yucatan. 
Table 4. Tryptophan Content ( $\mathrm{g}$ of amino acid/100 g of protein) in grains of Chichen Itza and Sac Beh in Lot 1 (low intensive use).

\begin{tabular}{cccc}
\hline $\begin{array}{c}\text { Fertilization } \\
\text { Treatment }\end{array}$ & Chichen Itza & Sac Beh & Average \\
\hline $00-00-00$ & 0.266 & 0.565 & 0.415 \\
$60-80-00$ & 0.346 & 0.345 & 0.345 \\
$60-80-00+$ Mico + Azo & 0.226 & 0.280 & 0.253 \\
Average & 0.279 & 0.396 & 0.337 \\
\hline
\end{tabular}

Control (00-00-00), the applied chemical fertilizer dose was (60 kg N/ha, $80 \mathrm{~kg} \mathrm{P}_{2} \mathrm{O}_{5} / \mathrm{ha}$ and $0 \mathrm{~kg} \mathrm{~K} / \mathrm{O} / \mathrm{ha}$ ); Chemical-Biofertilizers (60-80-00+ Mycorrhizae + Azospirillum) .

\subsection{Protein Content}

The general average value of total samples (Figure 1) was of $10.5 \% \pm 1.8 \%$, similar to the QPM materials reported by Mendoza et al., (2006) [20], of 10.53\%, $10.03 \%, 11.05 \%$ and $9.94 \%$ protein for QPM from CIMMYT. The average general values (Lot 1 plus Lot 2) of Sac Beh and Chichen Itza were similar with 10.48\% and $10.42 \%$ respectively; however, it was observed higher content in Lot 1 than in Lot 2. Protein contents were $10.9 \%$ and $11.0 \%$ for Sac Beh and Chichen Itza respectively in Lot 1 while in Lot 2 were $9.9 \%$ for Sac Beh and 10.1\% for Chichen Itza. The protein contents are similar to those found (9.35\%) for native Mayan maize (T'siit bakal and Xnuuc nal) found by Cázarez-Sánchez et al., in 2015 [21]. The chemical composition of grains can change with fertilization [22] and depends on the genotype [6] [23].

\subsection{Grain Ash Content}

A general mean of $1.42 \% \pm 0.6 \%$ found was similar to those reported $(0.85 \%$ to $1.42 \%$ ) by Mendoza et al., (2006) [20] for QPM varieties. The presence of minerals, indicated by ash content, is observed in Figure 2. Values ranging from 2.22\% to $0.66 \%$ were found in Lot 2 . The highest value being for Sac Beh in the ( $\mathrm{T}$ Chem-Sac) and the lowest one for Chichen Itza in the (T Chem-Bio-Chi) treatment. It can be seen in Figure 2 that ash content was higher in Sac Beh materials ( $1.96 \%$ average) compared to Chichen Itza ( $0.96 \%$ average). It indicates a greater mineral assimilation of Sac Beh as compared to Chichen Itza. Regardless of the lots, it was observed that (T Chem-Bio) had the lowest value (1.32\%) and (T Chem) the lowest one (1.58\%).

Table 5 shows different statistical groups resulting from the Tukey's test. Practically, in both lots, two groups are formed; the Sac Beh group with the highest values and the Chichen with the lowest ones. The highest value found in SacBeh was with (T Chem-Sac) while in the Chichen group the highest value was with (T Cnt-Chi). Under the same soil conditions, Sac Beh needs inorganic fertilization for higher mineral nutrients uptake than Chichen Itza. Both varieties, showed lowest mineral extraction with (T Chem-Bio). 


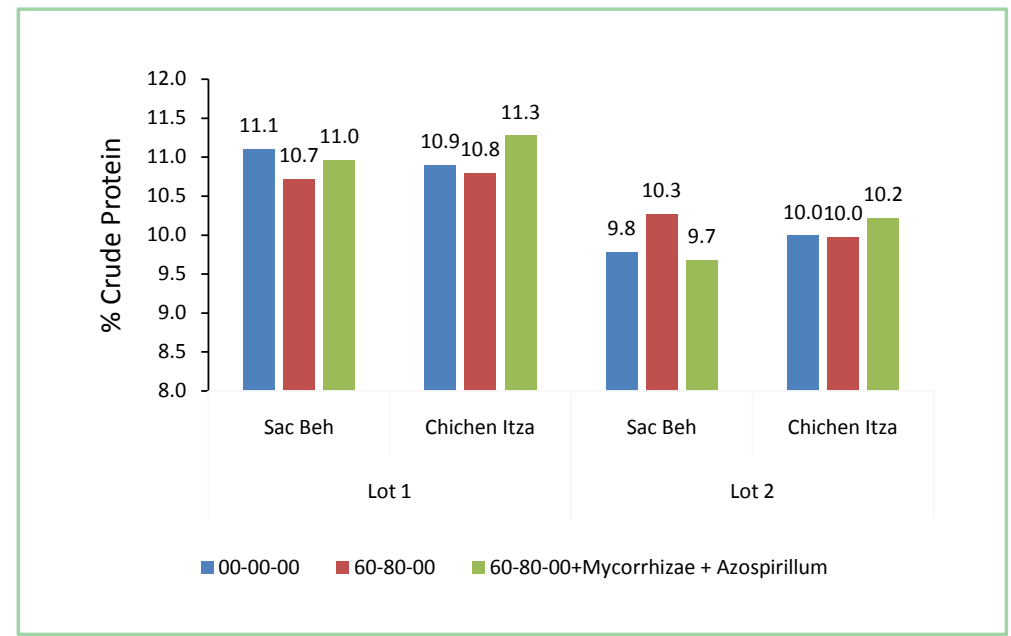

Figure 1. Protein content (\%) in Chichen Itza and Sac Beh varieties cultivated on Low (Lot 1) and High (Lot 2) Intensive use Luvisols under different fertilization treatments.

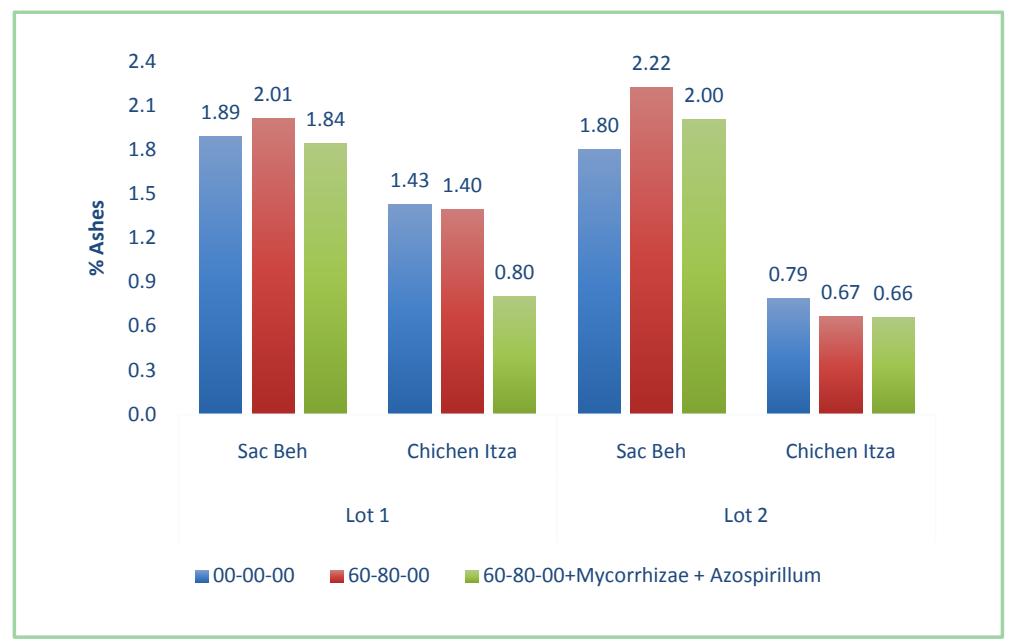

Figure 2. Ash Content (\%) in Chichen Itza and Sac Beh Varieties cultivated on Low (Lot 1) and High (Lot 2) intensive use Luvisols under different fertilization treatments.

Table 5. Comparison of means of Ash Content (\%) of Chichen Itza and Sac Beh under different treatments in two Luvisols of Yucatan Mexico.

\begin{tabular}{ccccc}
\hline \multirow{2}{*}{ Treatment } & \multicolumn{2}{c}{ Lot 1 } & \multicolumn{2}{c}{ Lot 2 } \\
\cline { 2 - 5 } & Average & Groups & Average & Groups \\
\hline T4 & 2.01 & $\mathrm{~A}$ & 2.22 & $\mathrm{~A}$ \\
T2 & 1.89 & $\mathrm{~A}$ & 1.80 & $\mathrm{~A}$ \\
T6 & 1.84 & $\mathrm{~A}$ & 2.01 & $\mathrm{~A}$ \\
T1 & 1.43 & $\mathrm{AB}$ & 0.79 & $\mathrm{~B}$ \\
T3 & 1.00 & $\mathrm{~B}$ & 0.67 & $\mathrm{~B}$ \\
T5 & 0.79 & $\mathrm{~B}$ & 0.66 & $\mathrm{~B}$ \\
\hline
\end{tabular}

T1 (00-00-00-Chichen Itza); T2 (00-00-00-Sac Beh); T3 (60-80-00-Chichen Itza); T4 (60-80-00-Sac Beh); T5 (60-80-00 + Mycorrhizae + Azospirillum-Chichen Itza); T6 (60-80-00 + Mycorrhizae + Azospirillum-Sac Beh). The applied chemical fertilizer dose was $\left(60 \mathrm{~kg} \mathrm{~N} / \mathrm{ha}, 80 \mathrm{~kg} \mathrm{P}_{2} \mathrm{O}_{5} / \mathrm{ha}\right.$ and $0 \mathrm{~kg} \mathrm{~K} 2 \mathrm{O} / \mathrm{ha}$ ). Control (00-00-00). 


\subsection{Quality Protein in Chichen Itza and Sac Beh}

\section{Lot 1. Tryptophan Content (Chichen Itza and Sac Beh)}

The absolute average contents of Tryptophan (Table 4) of both Chichen Itza and Sac Beh showed that, regardless of treatments, Sac Beh had 42\% more Tryptophan than Chichen Itza (0.396 vs 0.279). Chichen Itza accumulated more Tryptophan (0.346) when (T Chem-Chi) was applied instead of the (T Chem-Bio-Chi) (0.226). The (T Cnt-Chi) had similar Tryptophan content $(0.226)$ as the (T Chem-Bio-Chi).

Sac Beh, had the highest amount of Tryptophan (0.565) in the Control (T Cnt-Sac) and the lowest one (0.280) in (T Chem-Bio-Sac). There was a Tryptophan reduction when Biofertilizers are added. This trend can be seen in Table 6 . In absolute numbers, regardless of varieties, the Tryptophan average in ( $\mathrm{T}$ Chem-Bio) was found to be $0.253 \%$ followed by $0.345 \%$ and $0.415 \%$ for ( $\mathrm{T}$ Chem) and (T Cnt) respectively. In relative percentages, taking (T Chem-Bio) as a reference with $100 \%$, the ( $\mathrm{T}$ Chem) and (T Cnt) had $136 \%$ and $164 \%$ respectively.

\section{Lot 2. Tryptophan Content (Chichen Itza and Sac Beh)}

As in Lot 1, in Lot 2, regardless of treatments, the higher general Tryptophan average content (Table 7), was founded in Sac Beh with $0.453 \%$. This is $76 \%$ increase as related to the $0.257 \%$ showed by Chichen Itza. By instance, as for Chichen Itza in Lot 1 , the highest Tryptophan amount (0.345\%) was recorded, again, in the control (T Cnt-Chi). In Sac Beh the highest Tryptophan content was found with (T Chem-Bio-Sac).

Table 6. Lysine Content ( $\mathrm{g}$ of amino acid/100 $\mathrm{g}$ of protein) in grains of Chichen Itza and Sac Beh in Lot 1 (low intensive use).

\begin{tabular}{ccc}
\hline Fertilization Treatment & Chichen Itza & Sac Beh \\
\hline $00-00-00$ & 2.36 & 2.55 \\
$60-80-00$ & 1.76 & 2.29 \\
$60-80-00+$ Mico + Azo & 2.20 & 1.73 \\
Average & 2.10 & 2.19
\end{tabular}

Control (00-00-00), the applied chemical fertilizer dose was (60 Kg N/ha, $80 \mathrm{Kg} \mathrm{P}_{2} \mathrm{O}_{5} / \mathrm{ha}$ and $0 \mathrm{Kg} \mathrm{K} / \mathrm{O} / \mathrm{ha}$ ); Chemical-Biofertilizers (60-80-00 + Mycorrhizae + Azospirillum).

Table 7. Tryptophan Content ( $\mathrm{g}$ of amino acid/100 $\mathrm{g}$ of protein) in grains of Chichen Itza and Sac Beh in Lot 2 (low intensive use).

\begin{tabular}{cccc}
\hline Fertilization Treatment & Chichen Itza & Sac Beh & Average \\
\hline $00-00-00$ & 0.345 & 0.430 & 0.387 \\
$60-80-00$ & 0.191 & 0.435 & 0.313 \\
$60-80-00+$ Mico + Azo & 0.236 & 0.495 & 0.365 \\
Average & 0.257 & 0.453 & 0.355 \\
\hline
\end{tabular}

Control (00-00-00), the applied chemical fertilizer dose was (60 Kg N/ha, $80 \mathrm{Kg} \mathrm{P}_{2} \mathrm{O}_{5} / \mathrm{ha}$ and $0 \mathrm{Kg} \mathrm{K} 2 \mathrm{O} / \mathrm{ha}$ ); Chemical-Biofertilizers (60-80-00 + Mycorrhizae + Azospirillum). 


\section{Lot 1. Lysine Content}

The Lysine content found in kernels of Chichen Itza and Sac Beh grown in Lot 1 (low intensive use) is shown in Table 6. Although no statistical differences were found, it can be perceived that Sac Beh had slightly higher amount (2.19) than Chichen Itza (2.10). When viewing specific treatments, it is noted, for both varieties, a general trend of having higher amounts of Lysine in the control ( $\mathrm{T}$ $\mathrm{Cnt}$ ) than in ( $\mathrm{T}$ Chem-Bio). By instance, Chichen Itza had 2.36 in the ( $\mathrm{T}$ Cnt-Chi) and $2.20 \mathrm{~g}$ of Lys/100 g of protein in (T Chem-Bio-Chi) whilst the lowest value was found in the chemical treatment (T Chem-Chi) with 1.76. The same general path followed Sac Beh since (T Cnt-Sac) had 2.55 and the (T Chem-Bio-Sac) with biofertilizers had $1.73 \mathrm{~g}$ of Lys/100 $\mathrm{g}$ of protein.

\section{Lot 2. Lysine Content}

As in the case of Lot 1, in Lot 2 (Table 8) the same trend of Lysine content was found. Again, Sac Beh had a slight higher general average amount of the amino acid (2.49) than that of Chichen Itza (2.36). When comparing specific treatments, it was found that the control (T Cnt) showed the highest content with 2.91 and $2.81 \mathrm{~g}$ of Lys/100 $\mathrm{g}$ of protein for Chichen Itza and Sac Beh respectively followed by the Chemical treatment (T Chem) with 2.20 and 2.37 for both varieties respectively. Again, when biofertilizers were added (T-Chem-Bio), the accumulation of Lysine diminished 32\% for Chichen Itza (2.91 vs 1.99) and 18\% for Sac Beh (2.81 vs 2.31) when contents are compared to (T Cnt). On the other hand, there was a $25 \%$ Lysine reduction in Chichen Itza (2.91 vs 2.20) when chemical treatment (T Chem-Chi) was applied as compared to the (T Cnt-Chi). A $15.6 \%$ Lysine reduction (2.81 vs 2.37) was found in Sac Beh when comparing the same treatments.

\section{Tryptophan and Lysine Content $v s$ Literature}

Important differences were found when comparing the results of this work with those reported by the literature (Table 9). By instance, taking into consideration the reference average values as $0.8 \%$ for Tryptophan and $4.0 \%$ for Lysine (g of amino-acid/100 g of protein), reported by Vivek et al., (2008) [24] for CIMMYT's QPM maize, it's suggested that neither Chichen Itza nor Sac Beh reached both references values. The maximum Tryptophan and Lysine values for Chichen Itza were $0.346 \%$ (T Chem-Chi in Lot 2) and 2.91\% (T Cnt-Chi in Lot 1) respectively whilst Sac Beh had $0.565 \%$ (T Cnt-Sac in Lot in Lot 2) and $2.81 \%$ (T Cnt-Sac in Lot 1) for Tryptophan and Lysine.

Table 8. Lysine content ( $\mathrm{g}$ of amino acid/100 $\mathrm{g}$ of protein) in grains of Chichen Itza and Sac Beh in Lot 2 (low intensive use).

\begin{tabular}{ccc}
\hline Fertilization Treatment & Chichen Itza & Sac Beh \\
\hline $00-00-00$ & 2.91 & 2.81 \\
$60-80-00$ & 2.20 & 2.37 \\
$60-80-00+$ Mico + Azo & 1.99 & 2.31 \\
Average & 2.36 & 2.49 \\
\hline
\end{tabular}

Control (00-00-00), the applied chemical fertilizer dose was (60 Kg N/ha, $80 \mathrm{Kg} \mathrm{P}_{2} \mathrm{O}_{5} / \mathrm{ha}$ and $0 \mathrm{Kg} \mathrm{K} / \mathrm{O} / \mathrm{ha}$ ); Chemical-Biofertilizers (60-80-00 + Mycorrhizae + Azospirillum). 
Table 9. Literature References related to Tryptophan and Lysine content (g of amino ac$\mathrm{id} / 100 \mathrm{~g}$ of protein) for different QPM materials.

\begin{tabular}{cccc}
\hline Variety & Tryptophan & Lysine & Source of Information \\
\hline Normal Natives (Mixteca-Oaxaca) & 0.536 & 3.15 & Vera-Guzman et al., 2012 [26] \\
Normal Natives (Maya-Yucatan) & 0.912 & 2.91 & Cásarez-Sánchez et al., 2015 [21] \\
Normal Natives (Nayarit) & 0.480 & 2.90 & Vidal et al. 2008 [25] \\
Normal Maize (CYMMYT) & 0.400 & 2.80 & Vivek et al. 2008 [24] \\
QPM-H-564 C & 0.860 & 3.52 & Sierra et al. 2011 [27] \\
QPM-V2 & 0.640 & 3.75 & Mendoza et al. 2006 [20] \\
QPM Maize (CIMMYT) & 0.800 & 4.00 & Vivek et al. 2008 [24] \\
Chichen Itza & $0.279 / 0.257$ & $2.10 / 2.36$ & Current work \\
Sac Beh & $0.396 / 0.453$ & $2.19 / 2.49$ & Current work
\end{tabular}

Vidal et al., (2008) [25] mentioned that Tryptophan and Lysine in native maize from Nayarit Mexico were $0.480 \%$ and $2.90 \%$ respectively and Vera Guzman et al., (2012) [26] found $0.536 \%$ and $3.15 \%$ for the same proteins in native maize from the Mixteca Region of Oaxaca, Mexico. On the other hand, Cásarez-Sánchez et al., (2015) [21] found an outstanding higher amount of Trp (0.912\%) for Mayan maize such as the Xnuuc nal native one. Sierra et al., (2011) [27] reported values of 0.86 (Trp) and 3.52 (Lys) for QPM hybrid H-564 C. It seems that both varieties (Chichen Itza and Sac Beh) have been losing their protein quality, so it is important to confirm these results and give more attention to the issue of rescuing their high-quality protein.

\section{Conclusion}

No significant differences were found for yields and it was proved that Chichen Itza and Sac Beh have good yield potential in Luvisols of Yucatan, Mexico, regardless of intensive land use. Although the yields increased with the application of chemical fertilizers alone or in combination with biofertilizers, the amount of tryptophan and lysine decreased due to a probable relationship with the increase in total protein as is documented in other works. This makes evident that the variations of the protein quality are related to changes that the soil undergoes. Sac Beh showed to have better protein quality than Chichen Itza but none of them reached the optimal ranges reported by the literature, so more evidence is required to start with a plan to rescue and maintain the protein quality of both varieties.

\section{Conflicts of Interest}

The authors declare no conflicts of interest regarding the publication of this paper.

\section{References}

[1] Bautista, F., Palma-López, D. and Huchin-Malta, W. (2005) Updating of the Soil 
Classification of the State of Yucatan. In: Bautista, F. and Palacio, G., Eds., Characterization and Management of the Yucatan Peninsula Soils. Agricultural, Forestry and Environmental Implications, Autonomous University of Campeche, Autonomous University of Yucatan, National Institute of Ecology, 105-122.

https://www.researchgate.net/publication/313757781_Actualizacion de la clasifica cion de los suelos del estado de Yucatan

[2] Azevedo, R.A, Lancien, M. and Lea, P.J. (2006) The Aspartic Acid Metabolic Pathway, an Exciting and Essential Pathway in Plants. Amino Acids, 30, 143-162.

https://link.springer.com/article/10.1007/s00726-005-0245-2

https://doi.org/10.1007/s00726-005-0245-2

[3] Huang, S., Whitney, R.A., Zhou, Q., Malloy, K.P., Voyles, D.A., Anthony, J., Kriz, A.L. and Luethy, M.H. (2004) Improving Nutritional Quality of Maize Proteins by Expressing Sense and Antisense Zein Genes. Journal of Agricultural and Food Chemistry, 52, 1958-1964. https://doi.org/10.1021/jf0342223

[4] Ortega, C.A., Cota, A.O., Vasal, S.K., Villegas, M.E., Córdoba, O.H., Barreras, S.M.A., Wong, P.J.J., Reyes, M.C.A., Preciado, O.R.E., Terrón, I.A. and Espinoza, C.A. (2001) H-441C, H-442C and H-469C. Maize Hybrids of Improved Protein Quality for the Northwest and Sub-tropics of Mexico. Ed. INIFAP. Technical Brochure No. 41, 4-15.

[5] Aguilar-Castillo, G., Gómez, M.N., Torres, P.H. and Vázquez, C.G. (2010) SAC-BEH and CHICHEN ITZA: Protein Quality Maize Varieties for Shifting Cultivation in the Yucatan Peninsula. National Institute of Forestry, Agricultural and Livestock Research, Mococha Experimental Station, Southeast Regional Center, Technical Brochure No. 3, 17 p.

https://www.compucampo.com/tecnicos/variedades-maizcalidadprote\%C3\%ADnic a-yuc.pdf

[6] Vázquez-Carrillo, M.G., Escobedo-Monje, D., González-Cruz, A., Turrent-Fernández, A. and Tut-Couoh, C. (2005) Protein, Lysine and Tryptophan Contents in Protein Quality Maize (QPM) with Different Agronomic Management. Technical Agriculture in Mexico, 31, 191-202.

[7] Arévalo, L.R., Ruiz, M.S., Ferreira, S.A. and Riveros, G. (1979) Assessment of Lysine and Tryptophan in Different Varieties of Normal and Opaque 2 Corn. Colombian Journal of Chemical-Pharmaceutical Sciences, 3, 37-63. https://revistas.unal.edu.co/index.php/rccquifa/article/view/56662

[8] Alaíz, M., Navarro, J.L., Girón, J. and Vioque, E. (1992) Amino Acid Analysis by High-Performance Liquid Chromatography after Derivatization with Diethyl Ethoxymethylenemalonate. Journal of Chromatography A, 591, 181-186. https://doi.org/10.1016/0021-9673(92)80236-N

[9] Yust, M., Pedroche, J., Girón, J., Vioque, E., Millán, F. and Alaíz, M. (2004) Determination of Tryptophan by High-Performance Liquid Chromatography of Alkaline Hydrolysates with Spectrophotometric Detection. Food Chemistry, 85, 317-320. https://www.researchgate.net/publication/223927897 Determination of tryptopha n by high-performance liquid chromatography of alkaline hydrolysates with $s$ pectrophotometric detection/citation/download https://doi.org/10.1016/j.foodchem.2003.07.026

[10] Association of Official Analytical Chemists (AOAC) (1997) Official Methods of Analysis of the Association of Official Analytical Chemists. Method 954.01. 15th Edition, AOAC, Washington DC.

[11] Association of Official Analytical Chemists (AOAC) (1997) Official Methods of Analysis of the Association of Official Analytical Chemists. Method 923.03. 15th 
Edition, AOAC, Washington DC.

[12] Uribe-Valle, G. and Petit-Aldana, J. (2007) Contribution of Short Fallows in the Recovery of Soil Fertility in Milpas of the State of Yucatán, Mexico. Chapingo Magazine Forest and Environmental Science Series, 13, 137-142.

http://www.scielo.org.mx/scielo.php?pid=S2007-40182007000200137\&script=sci ab stract\&tlng $=\mathrm{pt}$

[13] Pimentel, F. (1985) Experimental Statistics Course. Livraria Novel S.A., Sao Paulo.

[14] Gomez, K.A. and Gomez, A.A. (1984) Statistical Procedures for Agricultural Research. 2nd Edition, John Wiley Inter Science, Hoboken.

[15] Martínez, A. (1988) Experimental Designs: Methods and Elements of Theory. Editorial Trillas. Mexico.

[16] Patel, J.K., Patel, N.M. and Shiyani, R.L. (2001) Coefficient of Variation in Field Experiments and Yardstick Thereof-An Empirical Study. Current Science, 81, 1163-1164. https://pdfs.semanticscholar.org/2e12/ac240249178564338c173fb608b592fe44e9.pdf

[17] Ayala-Contreras, C.A. (2015) Physiological Response to Salinity in Two Maize Genotypes. Professional Master Thesis. Grain and Seed Technology Department, Autonomous Agrarian University “Antonio Narro”, Saltillo. http://repositorio.uaaan.mx:8080/xmlui/handle/123456789/42513

[18] Rengasamy, P., North, S. and Smith, A. (2010) Diagnosis and Management in Soil and Water in the Murray Irrigation Region. Sodicity \& Salinity, Ed. Arris Pty Ltd., The University of Adelaide, Adelaide, 83 p.

[19] Bautista, F., Palma-López, D. and Huchin-Malta, W. (2005) Updating of the Soil Classification of the State of Yucatan. In: Bautista, F. and Palacio, G., Eds., Characterization and Management of the Yucatan Peninsula Soils. Agricultural, Forestry and Environmental Implications, Autonomous University of Campeche, Autonomous University of Yucatan, National Institute of Ecology, 33-58.

https://www.researchgate.net/publication/253953809 Integracion del conocimient o actual sobre los paisajes geomorfologicos de la peninsula de Yucatan

[20] Mendoza-Elos, M., Andrio-Enriquez, E., Juarez-Goiz, J.M., Mosqueda-Villagómez, C., Latourniere-Moreno, L., Castañon-Nájera, G., López-Benítez, A. and Moreno-Martínez, E. (2006) Lysine and Tryptophan content in High Protein and Normal Corn Genotypes. University and Science, 22, 153-161.

https://www.redalyc.org/pdf/154/15422206.pdf

[21] Cázares-Sánchez, E., Chávez-Servia, J.L., Salinas-Moreno, Y., Castillo-González, F. and Ramírez-Vallejo, P. (2015) Grain Composition Variation among Native Maize (Zea mays L.) of Yucatán, Mexico. Agroscience, 49, 15-30.

http://www.scielo.org.mx/scielo.php?pid=S1405-31952015000100002\&script=sci ar $\underline{\text { ttext }}$

[22] Zepeda-Bautista, R., Carballo-Carballo, A., Muñoz-Orozco, A., Mejía-Contreras, J.A., Figueroa-Sandoval, B., González-Cossio, F.V. and Hernández-Aguilar, C. (2009) Protein, Tryptophan, and Structural Kernel Components in Corn (Zea mays L.) Hybrids Cultivated under Fertirrigation. Agroscience, 43, 143-152.

http://www.scielo.org.mx/scielo.php?script=sci $\operatorname{arttext\& pid=S1405-3195200900020}$ $\underline{0006}$

[23] Méndez-Montealvo, G., Solorza-Feria, J., Velázquez del Valle, M., Gómez-Montiel, M., Paredes-López, O. and Bello-Pérez, L. (2005) Chemical Composition and Calorimetric Characterization of Hybrids and Varieties of Maize Cultivated in Mexico. Agroscience, 39, 267-274. https://www.redalyc.org/pdf/302/30239303.pdf 
[24] Vivek, B.S., Krivanek, A.F., Palacios-Rojas, N., Twumasi-Afriyie, S. and Diallo, A.O. (2008) Improvement of Corn with Protein Quality (QPM): Protocols to Generate QPM Varieties. CIMMYT, México, 66 p.

[25] Vidal, M.V.A., Vázquez, C.G., Coutiño, E.B., Corona, O.A., Ramírez, D.J.L., Valdivia, B.R., Guerrero, H.M.J., Caro, V.J.J. and Cota, A.O. (2008) Protein Quality in Maize Landraces from the Mountains of the State of Nayarit, México. Revista Fitotecnia Mexicana, 31, 15-21.

https://www.revistafitotecniamexicana.org/documentos/31-1\%20Especial\%203/4a.p df

[26] Vera-Guzman, A.M., Chavez-Servia, J.L. and Carrillo-Rodríguez, J.C. (2012) Protein, Lysine and Tryptophan in Native Populations of Mixteco Maize. Revista Fitotecnia Mexicana, 35, 7-13.

https://www.revistafitotecniamexicana.org/documentos/35-3 Especial 5/2a.pdf

[27] Sierra Macías, M., Palafox Caballero, A., Rodríguez Montalvo, F., Espinosa Calderón, A., Vázquez Carrillo, G., Gómez Montiel, N. and Barrón Freyre, S. (2011) H-564C, High Quality Protein Maize Hybrid for the Humid Tropic in Mexico. Mexican Magazine of Agricultural Sciences, 2, 71-84.

http://www.scielo.org.mx/scielo.php?script=sci arttext\&pid=S2007-0934201100010 $\underline{0006}$ 